\title{
The Association of Syphilis Infection and Other Risk Factors with Immunity of Patients with HIV on Anti-Retroviral Therapy
}

\author{
Pik Siong, B. Rina A. Sidharta, Amiroh Kurniati \\ Department of Clinical Pathology, Faculty of Medicine, Sebelas Maret University/Dr. Moewardi General Hospital, Surakarta, Indonesia. \\ E-mail: siong_hope14286@yahoo.com
}

\begin{abstract}
Syphilis infection, age, gender, sexual behaviour, length of HIV infection and length of ARV treatment are suspected to be associated with amount of cluster of differentiation $4\left(\mathrm{CD} 4^{+}\right) \mathrm{T}$-cells $\left(\mathrm{CD} 4^{+} \mathrm{T}\right.$-cell) and CD4 ${ }^{+} \mathrm{T}$-cells: CD8 ${ }^{+} \mathrm{T}$-cells ratio (CD4:CD8) of HIV patients on ARV. However, the evidence remains lacking. The aim of this cross-sectional study on April $24^{\text {th }}$ to June $20^{\text {th }}$, 2019 was to determine the association of syphilis infection and other risk factors (age, gender, sexual behavior, length of HIV infection and ARV treatment) with the immunity of patients with HIV on ARV based on T CD4 ${ }^{+}$and CD4:CD8, and got factors those have an influence to T CD4 ${ }^{+}$and CD4:CD8. Seventy-four subjects with age $\geq 18$ years old with HIV on ARV from Voluntary Counselling Test (VCT) Outpatients of Dr. Moewardi General Hospital in Surakarta (DMGHS) had been examined for syphilis, $\mathrm{T} \mathrm{CD}^{+}$count and CD4:CD8 in Clinical Pathology Laboratory of DMGHS. Other data had been completed from the anamnesis and VCT data system. All data had been processed with SPSS version 21. Multivariate logistic regression following bivariate analysis of the Chi-Square test was used for categorical variables. Bivariate analysis showed a significant association between age, length of HIV infection and length of ARV treatment to TCD4 ${ }^{+}$count and significant association between sexual behavior, length of HIV infection, and length of ARV treatment to CD4:CD8 $(p<0.05)$. Multivariate analysis showed that the prevalence of $\mathrm{Cd} 4 \leq 500$ was higher in male Prevalence Ratio $(P R)=3.256 ; p=0.038)$ than that of female and subjects aged $>42 y .0$. compared to those aged $>18-42$ y.o. ( $P R=3.451 ; p=0.047)$. The $P R$ of $C D 4: C D 8<0.3$ in anal sex $(P R=3.575 ; p=0.049)$ was higher than that of vaginal sex. The $P R$ of $C D 4 \leq 500(P R=0.271 ; p=0.020)$ and $C D 4: C D 8<0.3(P R=0.125 ; p=0.001)$ in subjects with length of $\mathrm{HIV}>5$ years were lower than those in HIV 0-5 years. Age, gender, and length of HIV potentially affect the probability of $\mathrm{TCd} 4^{+} \leq 500$. Sexual behavior and length of HIV potentially affect the probability of CD4:CD8 < 0.3. Both CD4 and CD4:CD8 ratio must be tested at baseline and follow-up.
\end{abstract}

Keywords: T CD4+ CD4:CD8, prevalence ratio, syphilis, HIV, probability

\section{INTRODUCTION}

Human Immunodeficiency Virus (HIV) is a single-stranded ribonucleic acid (RNA) lentivirus, which causes HIV infection/Acquired Immunodeficiency Syndrome (AIDS). ${ }^{1,2}$ In 2015 there were 36.7 million people with HIV/AIDS worldwide. There were 2,270 HIV cases in Central Java in 2017 dominated by male and 25-49 years old group. There were 1,409 AIDS cases in Central Java in 2017 with $66.36 \%$ males and $72.96 \%$ aged $25-49$ years old with the highest mortality in this age group. In Surakarta, it was reported that there were 118 new HIV cases in 2017 comprised of 57 HIV and 61 AIDS. A higher number of the male were affected by HIV than the female due to the increase of Male Sex Male (MSM) and Female Sex Worker (FSW) users with the mortality found in 7 males and 2 females..$^{3.4}$ The service for sexually transmitted and HIV infections in FSWs in Surakarta was limited and focused more on HIV infection.
Treponema pallidum, the bacterium causing syphilis is transmitted via sexual intercourse, maternal to fetal, and blood transfusion. ${ }^{6,7}$ Syphilis population reached 12 million people in 1999 worldwide and more than $90 \%$ of cases were found in developing countries. There were 181 syphilis cases in 2017 in Central Java which occurred mostly in people aged $25-49$ years old (59.67\%) and male (60.77\%). ${ }^{3}$ Syphilis was found predominantly in HIV patients, especially those who did MSM. ${ }^{8}$

Syphilis genital ulcers increase HIV transmission and infection. Simple columnar epithelium of anal mucosa is susceptible to damage, thereby facilitating HIV infection to lamina propria which is rich in lymphocytes. The risk of HIV transmission through receptive anal intercourse is higher than that of vaginal. ${ }^{9}$ Higher HIV viral load and lower CD4 are caused by further T CD4 $4^{+}$depletion, failure of both HIV and syphilis therapies, and development to neurosyphilis had been reported in HIV-syphilis co-infection. HIV-syphilis co-infection causes more 
difficulties in establishing syphilis diagnosis and worse clinical features of syphilis. ${ }^{10,11}$ These difficulties and complications commonly occur in high-risk sexual behavior and HIV-syphilis coinfection. ${ }^{1}$

The immune system of HIV patients is influenced by many factors. Demographic factors (age, gender, sexual behavior, education, occupation, marriage, income, proximity to health facilities), clinical factors (risk, initial clinical stage, baseline lymphocyte and $\mathrm{T} \mathrm{CD}^{+}$count, other infections), and treatment factors (regimen, compliance, length of treatment) are considered to affect the immune response of HIV patients. ${ }^{12-14}$

Gender is thought to influence the immunity. In healthy population, male had higher CD8 $(p>0.05)$ and CD8 percentage $(\% C D 8)(p<0.01)$ than female. ${ }^{15}$ leukocyte count, $\mathrm{T} \mathrm{CD4} 4^{+}$count, \% T CD4 ${ }^{+}$and CD4:CD8 ratio in female were higher than male. General immune activation, inflammation activation, innate immune response and their interferon-alpha level in female were also found higher than male. Females have a $40 \%$ lower HIV viral load, despite their faster progression to AIDS compared to males with the same viremia levels. A study by Prasetyo and Zaini reported that the differences in CD4 counts in healthy population between male and female were not significant and healthy males often had CD4 count less than 500 cells $/ \mu \mathrm{L}$, as it is related with testosterone, androgen and glucocorticoid. ${ }^{9,15,16}$

Age is one of HIV transmission risk factors. People age between 20 and 39 years old are sexually active. Elderly people with HIV have a higher risk of worsening to AIDS-associated with immunosenescent, thymus involution, slower therapeutic response and post anti-retroviral (ARV) reconstitution, higher expression of the chemokine receptor, lower production of interleukin (IL)-2 and its receptors with more intolerance to side effects of ARV toxicity. ${ }^{9,16-17}$ In addition to a study by Prasetyo and Zaini, a study by Yusra et al., showed similar findings that older age groups had a greater risk of $\mathrm{T} \mathrm{CD}^{+}<500$ cells $/ \mu \mathrm{L}$, while Uppal et al. suggested that differences in immunity were not significant among age groups. ${ }^{5-17}$

$\mathrm{T} \mathrm{CD4} 4^{+}$cell count and identification of other diseases/opportunistic infections must be carried out for the classification of immunodeficiency and prophylaxis for opportunistic infection. The anti-retroviral drug is immediately administered to people with HIV/AIDS (PLWHA) without considering clinical stadium and $\mathrm{T}_{\mathrm{CD}}{ }^{+}$count. Patients who started receiving ARV with the $\mathrm{T} \mathrm{CD4^{+ }}$ of $>500$ cells/ $\mu \mathrm{L}$ had a lower risk of worsened progression of AIDS/non-AIDS compared to those with $\mathrm{T} \mathrm{CD}^{+}$ $\geq 300$ cells/ $\mu \mathrm{L}$. Insignificant, mild, advanced and severe immunosuppression status can be presented as $\mathrm{T} \mathrm{CD4}^{+}>500$ cells $/ \mu \mathrm{L}, 350-499$ cells $/ \mu \mathrm{L}, 200-349$ cells $/ \mu \mathrm{L}$, and $<200$ cells $/ \mu \mathrm{L}$, respectively. ${ }^{18,19}$ After ARV treatment, the $\mathrm{T} \mathrm{CD4} 4^{+}$count should increase 100-140 cells/ $\mu \mathrm{L}$ per year with an acceleration response in the first 3 months. ${ }^{7}$ Approximately 10\% of HIV patients with ARV developed to AIDS in less than five years. ${ }^{9}$ A five-year fatality rate of AIDS was $100 \%{ }^{20}$ Depletion of T CD4 ${ }^{+}$count was accompanied by increased $\mathrm{T} C D 8^{+}$, leading to inverted $\mathrm{CD} 4: \mathrm{CD} 8$ ratio. $^{21}$

People with HIV/AIDS who started ARV with CD4:CD8 > 0.5 have greater possibility of its normalization. ${ }^{22}$ Non-AIDS events in PLWHA with CD4:CD8 $<0.3$ were 2 times higher than those with CD4:CD8 0.3- 0.45 or $>0.45{ }^{23}$

Studies about the effects of age, gender, syphilis infection, sexual behavior, length of HIV, and length of ARV on the immunity status of the HIV population with syphilis remain unclear with various results. This study aimed to determine the association of syphilis infection and other risk factors with the immunity of HIV patients on ARV.

\section{METHODS}

A cross-sectional study was performed from April $24^{\text {th }}$ to June $20^{\text {th }}, 2019$ with the permission of the Ethics Committee of Dr. Moewardi General Hospital Surakarta with number 544/IV/HREC/2019. Purposive sampling involved subjects from VCT in Dr. Moewardi General Hospital (DMGH) aged $\geq 18$ years old.

This research involved 74 patients with HIV aged $\geq 18$ years old who routinely took ARV from VCT in $\mathrm{DMGH}$. All of them had assigned informed consent. They had been examined for syphilis using SD Syphilis 3.0 (Multi) Bioline and Venereal Disease Research Laboratory (VDRL) Plasmatec. FACSCanto II flow cytometer was used for CD4 count and CD4:CD8 ratio tests. The exclusion criteria were subjects with lipemic, hemolysis, and icteric samples for syphilis test; clotting formation in tubes with ethylenediaminetetraacetic acid (EDTA); incomplete data (age, gender, sexual behavior, baseline CD4, length of HIV and length of ARV) and false positive or false negative results of syphilis test which needed confirmation. There was no lipemic, hemolysis, and icteric samples. Sample with any different results of syphilis examinations (Bioline or Plasmatec) was excluded to avoid false positive or false negative of syphilis test results. All tests were carried out in the Clinical Pathology Installation of DMGH Surakarta. 
Statistical analysis was performed with SPSS 21. Mann-Whitney and T-test were used to determine the differences in characteristic data. Dependent and independent variables have been categorized into two categories. Categorical data were analyzed using bivariate analysis of the Chi-Square test. All variables with $p$-value $<0.25$ were analyzed using backward multivariate logistic regression and a $p$-value of $<0.05$ was considered significant.

\section{RESULTS AND DISCUSSION}

Precision test results of $\mathrm{T} C D 4^{+}$and $\mathrm{CD} 4: \mathrm{CD} 8$ with FACSCanto II using human blood from the healthy donor (both syphilis and HIV non-reactive) showed that difference between tests was $\leq 50$ cells $/ \mu \mathrm{L}$ and coefficient of variation was $<10 \%$ as recommended by The United States Department of Health and
Human Services and protocol of World Health Organization, indicating that BD FACSCanto II instrument was proper to be used. Precision, minimum value, maximum value, and $\mathrm{CV}$ of $\mathrm{T} C D 4^{+}$ count were $888.56 \pm 3.979,883.17,892.25$, and 0.45 , respectively. In addition, precision, minimum value, maximum value, and CV of CD4:CD8 were $0.988 \pm 0.051,0.94,1.07$, and 5.13 , respectively. ${ }^{24,25}$

Most of the subjects in this study were senior high school graduates (Table 1). One research showed that low educational background followed by a lack of knowledge had significant effects on HIV/AIDS incidence..$^{20}$ Another study showed that education background was not related to the risk of immunological failure. ${ }^{26}$ The immune response of HIV patients were influenced by demographic, clinical, and treatment factors. ${ }^{17}$

Table 1. Characteristic data of subjects based on $T C D 4^{+}$count and $C D 4: C D 8$ ratio

\begin{tabular}{|c|c|c|c|c|c|c|c|}
\hline \multirow{2}{*}{ Parameter } & \multirow{2}{*}{$\begin{array}{c}\text { Total } \\
n=74 \\
(100 \%)\end{array}$} & \multicolumn{2}{|c|}{ T CD4 ${ }^{+}$Count } & \multirow{2}{*}{$\mathbf{P}$} & \multicolumn{2}{|c|}{ CD4:CD8 } & \multirow{2}{*}{$\mathbf{P}$} \\
\hline & & $\leq 500(n=46)$ & $>500(n=28)$ & & $<0.3(n=27)$ & $\geq 0.3(n=47)$ & \\
\hline \multicolumn{8}{|l|}{ Education } \\
\hline Elementary & $\begin{array}{c}n=9 \\
(12.16 \%)\end{array}$ & 6 (13.04\%) & 3 (10.71\%) & & 6 (22.22\%) & 3 (6.38\%) & \\
\hline Junior HS & 10 (13.51\%) & 7 (15.22\%) & 3 (10.71\%) & & 4 (14.81\%) & 6 (12.77\%) & \\
\hline Senior HS/equal & | 44 (59.46\%) & 29 (63.05\%) & 15 (53.58\%) & & 13 (48.15\%) & 31 (65.96\%) & \\
\hline Diploma & 6 (8.11\%) & 3 (6.52\%) & 3 (10.71\%) & & 3 (11.12\%) & 3 (6.38\%) & \\
\hline Bachelor & 5 (6.76\%) & 1 (2.17\%) & 4 (14.29\%) & & $1(3.70 \%)$ & 4 (8.51\%) & \\
\hline \multicolumn{8}{|l|}{ Occupation } \\
\hline Entrepreneur & 6 (8.11\%) & 3 (6.52\%) & 3 (10.71\%) & & $0(0 \%)$ & 6 (12.77\%) & \\
\hline Private sector & 34 (45.95\%) & 20 (43.48\%) & 14 (50\%) & & 8 (29.63\%) & 26 (55.31\%) & \\
\hline Employee & $11(14.86 \%)$ & 9 (19.57\%) & $2(7.15 \%)$ & & 7 (25.93\%) & 4 (8.51\%) & \\
\hline Labor & 4 (5.41\%) & 1 (2.17\%) & 3 (10.71\%) & & 1 (3.7\%) & 3 (6.38\%) & \\
\hline Merchant & $2(2.70 \%)$ & 1 (2.17\%) & $1(3.57 \%)$ & & 1 (3.7\%) & 1 (2.13\%) & \\
\hline Farmer & 2 (2.70\%) & $2(4.35 \%)$ & $0(0 \%)$ & & $1(3.7 \%)$ & 1 (2.13\%) & \\
\hline Housewife & 13 (17.57\%) & 8 (17.39\%) & 5 (17.86\%) & & 7 (25.93\%) & 6 (12.77\%) & \\
\hline Scholars & $2(2.70 \%)$ & $2(4.35 \%)$ & 0 (0\%) & & 2 (7.41\%) & 0 (0\%) & \\
\hline \multicolumn{8}{|l|}{ Marriage } \\
\hline No & 17 (22.97\%) & 12 (26.09\%) & 5 (17.86\%) & & 11 (40.74\%) & 6 (12.77\%) & \\
\hline Yes & 57 (77.03\%) & 34 (73.91\%) & 23 (82.14\%) & & 16 (59.26\%) & 41 (87.23\%) & \\
\hline \%CD4 (\%) & $18.5 \pm 8.2^{1}$ & $14,3 \pm 6.6^{1}$ & $25.4 \pm 5.6^{1}$ & $0.0001^{1}$ & $10.3 \pm 4.4^{1}$ & $23.2 \pm 5.9^{1}$ & $0.0001^{1}$ \\
\hline $\begin{array}{l}\text { Baseline T CD4 } \\
\text { (cells/uL) }\end{array}$ & $\begin{array}{c}44.37 \\
(31.2-63.1)^{1}\end{array}$ & $\begin{array}{c}31.54 \\
(24.6-48.7)^{1}\end{array}$ & $\begin{array}{c}138 \\
(3.0-641.8)^{2}\end{array}$ & $0.005^{2}$ & $\begin{array}{c}34.8 \\
(19.3-62.8)^{1}\end{array}$ & $\begin{array}{c}66 \\
(3.0-641.8)^{2}\end{array}$ & $0.138^{2}$ \\
\hline $\begin{array}{l}\text { Delta T CD4 } 4^{+} \\
\text {(cells/uL) }\end{array}$ & $336.2 \pm 235.5^{1}$ & $196.3 \pm 143.7^{1}$ & $566.1 \pm 165.6^{1}$ & $0.0001^{1}$ & $145.9 \pm 142.4^{1}$ & $445.5 \pm 207.6^{1}$ & $0.0001^{1}$ \\
\hline $\begin{array}{l}\mathrm{T}^{\mathrm{T}} \mathrm{CD} 8^{+} \\
\text {(cells/uL) }\end{array}$ & $\begin{array}{c}999.08 \\
(899-1,111)^{1}\end{array}$ & & & & $\begin{array}{c}497.16 \\
(371-667)^{1}\end{array}$ & $\begin{array}{c}985.37 \\
(887-1,095)^{1}\end{array}$ & $0.38^{1}$ \\
\hline
\end{tabular}

Note: HS: High School CD: Cluster of Differentiation; ${ }^{1}$ mean \pm SD, geometric mean (95\% confidence interval), T-test, data display of normally or abnormally distributed data; ${ }^{2}$ median (minimum-maximum), Mann-Whitney test, data display of abnormally distributed data; ${ }^{3}$ Chi-Square or Fisher' exact test; $\mathrm{n}$ : number 
Table 2. Difference tests between variables

\begin{tabular}{|c|c|c|c|c|c|c|c|}
\hline \multirow{2}{*}{ Variable } & \multirow{2}{*}{$\begin{array}{c}\text { Total } \\
74 \text { (100\%) }\end{array}$} & \multicolumn{2}{|c|}{$\mathrm{T} \mathrm{CD4}^{+}$} & \multirow{2}{*}{$\mathbf{P}$} & \multicolumn{2}{|c|}{ CD4:CD8 } & \multirow{2}{*}{$\mathbf{P}$} \\
\hline & & $\leq 500(n=46)$ & $>500(n=28)$ & & $<0.3(n=27)$ & $\geq 0.3(n=47)$ & \\
\hline Gender & & & & $0.016^{3}$ & & & $0.074^{3}$ \\
\hline Male & 37 (50\%) & 28 (60.87\%) & 9 (32.14\%) & & $\begin{array}{c}17 \\
(62.96 \%)\end{array}$ & 20 (42.55\%) & \\
\hline Female & 37 (50\%) & 18 (39.13\%) & 19 (67.86\%) & & $\begin{array}{c}10 \\
(37.04 \%)\end{array}$ & 27 (57.45\%) & \\
\hline Age & $39.74 \pm 9.69^{1}$ & $40.55 \pm 10.03^{1}$ & $38.40 \pm 9.13^{1}$ & $0.279^{1}$ & $\begin{array}{c}37.71 \\
(33.4-42.6)^{1}\end{array}$ & $39.90 \pm 8.09^{1}$ & $0.298^{1}$ \\
\hline$>42$ y.o & 28 (37.84\%) & 20 (43.48\%) & 8 (28.57\%) & & $\begin{array}{c}11 \\
(40.74 \%)\end{array}$ & 17 (36.17\%) & \\
\hline $18-42$ у.о & 46 (62.16\%) & 26 (56.52\%) & 20 (71.43\%) & & $\begin{array}{c}16 \\
(59.26 \%)\end{array}$ & 30 (63.83\%) & \\
\hline Sexual behavior & & & & $0.500^{3}$ & & & $0.007^{3}$ \\
\hline Anal & 17 (22.97\%) & 11 (23.91\%) & $6(21.43 \%)$ & & $\begin{array}{c}11 \\
(40.74 \%)\end{array}$ & 6 (12.77\%) & \\
\hline Vaginal & 57 (77.03\%) & 35 (76.09\%) & 22 (78.57\%) & & $\begin{array}{c}16 \\
(59.26 \%)\end{array}$ & 41 (87.23\%) & \\
\hline Syphilis infection & & & & $0.497^{3}$ & & & $0.229^{3}$ \\
\hline Yes & 12 (16.22\%) & 8 (17.39\%) & 4 (14.29\%) & & $\begin{array}{c}6 \\
(22.22 \%)\end{array}$ & 6 (12.77\%) & \\
\hline No & 62 (83.78\%) & 38 (82.61\%) & 24 (85.71\%) & & $\begin{array}{c}21 \\
(77.78 \%)\end{array}$ & 41 (87.23\%) & \\
\hline $\begin{array}{l}\text { Length of HIV } \\
\text { (years) }\end{array}$ & $\begin{array}{c}4.18 \\
(0.63-11.25)^{2}\end{array}$ & $2.94(2.32-3.73)^{1}$ & $5.95 \pm 2.68^{1}$ & $0.005^{1}$ & $\begin{array}{c}2.0 \\
(1.49-2.69)^{1}\end{array}$ & $5.83 \pm 2.58^{1}$ & \\
\hline$>5$ years & 33 (44.59\%) & 31 (67.39\%) & 18 (64.29\%) & & $\begin{array}{c}4 \\
(14.81 \%)\end{array}$ & 29 (61.70\%) & $0.0001^{1}$ \\
\hline $0-5$ years & 41 (55.41\%) & 15 (32.61\%) & 10 (35.71\%) & & $\begin{array}{c}23 \\
(85.19 \%)\end{array}$ & 18 (38.30 \%) & \\
\hline $\begin{array}{l}\text { Length of } \\
\text { ARV }\end{array}$ & $\begin{array}{c}4.09 \\
(0.61-11.25)^{2}\end{array}$ & $2.81(2.22-3.57)^{1}$ & $5.71 \pm 2.55^{1}$ & $0.0001^{1}$ & $\begin{array}{c}1.87 \\
(1.42-2.48)^{1}\end{array}$ & $5.71 \pm 2.55^{1}$ & \\
\hline $0-5$ years & 41 (55.41\%) & 11 (23.91\%) & 10 (35.71\%) & & $\begin{array}{c}23 \\
(85.19 \%)\end{array}$ & 18 (38.30\%) & $0.0001^{1}$ \\
\hline$>5$ years & $33(44.59 \%)$ & 35 (76.09\%) & 18 (64.29\%) & & $\begin{array}{c}4 \\
(14.81 \%)\end{array}$ & 29 (61.70\%) & \\
\hline T CD4 ${ }^{+}$count & $444.32 \pm 259.86^{1}$ & $277.27 \pm 130.01^{1}$ & $718.75 \pm 169.59^{1}$ & $0.0001^{1}$ & $\begin{array}{c}197 \\
(13.17618)^{2}\end{array}$ & $564.46 \pm 232.51^{1}$ & $0.0001^{2}$ \\
\hline$>500 / \mathrm{uL}$ & 28 (37.84\%) & & & & $\begin{array}{c}2 \\
(7.41 \%)\end{array}$ & 26 (55.31\%) & \\
\hline$\leq 500 / \mathrm{uL}$ & $46(62.16 \%)$ & & & & $\begin{array}{c}25 \\
(92.59 \%)\end{array}$ & 21 (44.69 \%) & \\
\hline CD4:CD8 ratio & $0.433 \pm 0.245^{1}$ & $0.32 \pm 0.17^{1}$ & $0.62 \pm 0.23^{1}$ & $0.0001^{1}$ & $\begin{array}{c}0.21 \\
(0.03-0.29)^{2}\end{array}$ & $\begin{array}{c}0.54 \\
(0.49-0.59)^{2}\end{array}$ & $0.0001^{2}$ \\
\hline
\end{tabular}

Note: ${ }^{1}$ mean \pm SD, geometric mean (95\% confidence interval), T-test, data display of normally or abnormally distributed data; ${ }^{2}$ median (minimum-maximum), Mann-Whitney test, data display of abnormally distributed data; ${ }^{3} \mathrm{Chi}$-Square or Fisher' exact test; n: number; HIV: Human Immunodeficiency Virus; CD: Cluster of Differentiation 
Most of the subjects worked with the private sector. Some researchers found that PLWHA who settle indeed lack of stress, risk or work pressure, leading to better immune status and vice versa. ${ }^{27-29}$ Another study showed that employment was not related to the immunological failure of PLWHA. ${ }^{26}$ Stress and financial condition were able to promote risky sexual behavior. ${ }^{30}$

The number of married subjects was greater than unmarried ones. This was in accordance with the studies by Saktina and Bagus. ${ }^{28}$ Another study reported that the lowest incidence of HIV was found in the married subjects who live together compared to those who live together with their sexual partners, single, widowed and divorced. ${ }^{31}$

The $\mathrm{T} \mathrm{CD4}^{+} \leq 500$ cells/ $\mu \mathrm{L}$ group was dominated by male subjects, while the $\mathrm{T} \mathrm{CD4}^{+}>500$ cells $/ \mu \mathrm{L}$ group was dominated by female subjects $(p=0.074)$ (Table 2). This was in accordance with a study by Klatt and Iswara et al. ${ }^{9,26}$ However, different results were found in the study by Adiningsih et al. They reported that females with HIV had a higher risk of immunodeficiency than males. ${ }^{27}$ Prasetyo and Zaini suggested that the difference of $\mathrm{T} \mathrm{CD}^{+}$count between male and female in healthy populations was not significant. ${ }^{16}$ Susilowati et al. revealed that there was no relationship between gender and the incidence of HIV/AIDS. ${ }^{20}$ Olsen and Kovacs in 2011 showed that there was an association between the hypogonadal condition and increased thymic output of T-cells thus increasing recent thymic emigrants in peripheral blood that will be reversed by androgen replacement. ${ }^{32}$ The CCR5 expression modulated by sex hormones is still controversial. Study of HIV-1-seronegative individuals showed that the density but not the percentage of $C \mathrm{CR} 5^{+} \mathrm{CD} 4^{+} \mathrm{T}$-cells was lower in females than in males. The CCR5 acts as HIV-1 coreceptor to enter and infect target cells such as $\mathrm{T} \mathrm{CD} 4^{+33}$. This study found that age, sexual behavior, and syphilis infection were insignificantly associated with $\mathrm{TCD}^{+}$(Table 3).

The prevalence of $\mathrm{TCD}^{+}$cell $\leq 500$ cells $/ \mu \mathrm{L}$ in subjects with HIV $>5$ years was (3/5) times significantly lower than subjects with $0-5$ years of HIV infection. Su et al. suggested that the interval between HIV diagnosis and the initiation of ARV had bad effects on adherence and outcome. Every 100 days of extensive pre-treatment waiting time increased loss to follow-up by $20 \%$ and mortality rate by $11 \% .{ }^{34}$ This study population was HIV patients on ARV. The median duration gap between HIV diagnosis and start of ARV treatment was 14.6 days

Table 3. Cross tabulation of categorical variables

\begin{tabular}{|c|c|c|c|c|c|c|c|c|}
\hline \multirow{2}{*}{ Variable } & \multicolumn{2}{|c|}{$\mathrm{T} \mathrm{CD4}^{+}$} & \multirow{2}{*}{ PR (95\% CI) } & \multirow{2}{*}{$\mathbf{p}$} & \multicolumn{2}{|c|}{ CD4:CD8 } & \multirow{2}{*}{ PR (95\% CI) } & \multirow{2}{*}{$\mathbf{p}$} \\
\hline & $\leq 500$ & $>500$ & & & $<0.3$ & $\geq 0.3$ & & \\
\hline \multicolumn{3}{|l|}{ Gender } & 1.556 & \multirow[t]{3}{*}{$0.016^{*}$} & & & \multirow{3}{*}{$\begin{array}{c}1.700 \\
(0.901-3.206)\end{array}$} & \multirow[t]{3}{*}{0.074} \\
\hline Male & 28 & 9 & \multirow[t]{2}{*}{$(1.066-2.270)$} & & 17 & 20 & & \\
\hline Female & 18 & 19 & & & 10 & 27 & & \\
\hline \multicolumn{3}{|l|}{ Age (years) } & 1.264 & \multirow[t]{3}{*}{0.151} & & & 1.129 & \multirow[t]{3}{*}{0.444} \\
\hline$>42$ & 19 & 8 & \multirow[t]{2}{*}{$(0.895-1.785)$} & & 10 & 17 & \multirow[t]{2}{*}{$(0.615-2.073)$} & \\
\hline $18-42$ & 27 & 20 & & & 17 & 30 & & \\
\hline \multicolumn{3}{|c|}{ Sexual behavior } & 1.054 & \multirow[t]{3}{*}{0.500} & & & \multirow{3}{*}{$\begin{array}{c}2.305 \\
(1.338-3.972)\end{array}$} & \multirow[t]{3}{*}{$0.007^{*}$} \\
\hline Anal & 11 & 6 & \multirow[t]{2}{*}{$(0.701-1.583)$} & & 11 & 6 & & \\
\hline Vaginal & 35 & 22 & & & 16 & 41 & & \\
\hline \multicolumn{3}{|c|}{ Syphilis infection } & 1.088 & \multirow[t]{3}{*}{0.497} & & & \multirow{3}{*}{$\begin{array}{c}1.476 \\
(0.760-2.868)\end{array}$} & \multirow[t]{3}{*}{0.229} \\
\hline Yes & 8 & 4 & \multirow[t]{2}{*}{$(0.696-1.700)$} & & 6 & 6 & & \\
\hline No & 38 & 24 & & & 21 & 41 & & \\
\hline \multicolumn{3}{|c|}{ Length of HIV (years) } & 0.601 & \multirow[t]{3}{*}{$0.008^{*}$} & & & \multirow{3}{*}{$\begin{array}{c}0.216 \\
(0.083-0.563)\end{array}$} & \multirow[t]{3}{*}{$0.0001^{*}$} \\
\hline$>5$ & 31 & 18 & \multirow[t]{2}{*}{$(0.398-0.908)$} & & 4 & 29 & & \\
\hline $0-5$ & 15 & 10 & & & 23 & 18 & & \\
\hline \multicolumn{3}{|c|}{ Length of ARV (years) } & 1.663 & $0.008^{*}$ & & & \multirow{3}{*}{$\begin{array}{c}4.628 \\
(1.776-12.060)\end{array}$} & \multirow[t]{3}{*}{$0.0001^{*}$} \\
\hline $0-5$ & 11 & 10 & $(1.101-2.512)$ & & 23 & 18 & & \\
\hline$>5$ & 35 & 18 & & & 4 & 29 & & \\
\hline
\end{tabular}

${ }^{*}$ p-value<0.05 significant, HIV: Human Immunodeficiency Virus, CD: Cluster of Differentiation, ARV: anti-retroviral, PR: Prevalence Ratio, CI: Confidence Interval 
and the modus was 0 day (HIV diagnosis and the start of $A R V$ were in the same day), indicating that length HIV infection is in line with a length of ARV, that more viruses were eradicated, leading to the elevated $\mathrm{T} \mathrm{CD}^{+}$count and the lower prevalence of $\mathrm{T} \mathrm{CD}^{+}$ $\leq 500$ cells $/ \mu \mathrm{L}$.

The prevalence of CD4 cell count of $\leq 500$ cells $/ \mu \mathrm{L}$ in HIV subjects with ARV 0-5 years was 1.66 times significantly higher than subjects with ARV $>5$ years. This was consistent with the study by Adiningsih et al. ${ }^{27}$ Activation of T-cells (co-expression of CD38 and HLA-DR on the T-cell surface) and T-cell exhaustion (expression of programmed cell death 1 (PD-1)) occurred after four years of ARV therapy. Activation and exhaustion of $\mathrm{CD} 4^{+}$and $\mathrm{CD} 8^{+} \mathrm{T}$-cells were significantly higher in patients with suboptimal $\mathrm{CD} 4^{+} \mathrm{T}$-cells reconstitution compared to optimal and superoptimal responders $(p<0.05)$. Increased apoptosis and intrinsic T-cell death play a role in incomplete recovery of $\mathrm{CD}^{+}{ }^{+}$-cells count. Programmed cell death-1 expression is increased during HIV-1 infection and negatively regulates T-cell activity. There are conflicting data on the influence of $\mathrm{T}$-cell activation on $\mathrm{CD}^{+} \mathrm{T}$-cell recovery among patients with successful ARV. ${ }^{35}$ Other literature said that the $\mathrm{CD}^{+} \mathrm{T}$-cell amount still increased in subjects with ARV for 5-7 years. CD4 $T$ count below the normal range despite ARV therapy showed insufficient suppression of HIV replication and/or start of ARVs in older age. ${ }^{36}$

This research findings gender, age, and syphilis infection were insignificantly associated with a $C D 4: C D 8$ ratio. The difference in $C D 4: C D 8$ ratio between acute and chronic HIV infection with/without syphilis was not significant. ${ }^{8}$ The likelihood of CD4:CD8 ratio normalization after 72 weeks of ARV in HIV alone was greater than HIV-syphilis co-infection. ${ }^{37}$

The prevalence of CD4:CD8 ratio < 0.3 in HIV subjects with anal sexual behavior was 2.305 times significantly higher than those with vaginal sexual behavior. The gastrointestinal mucosa is uniquely susceptible to HIV-1 infection and supportive of HIV-1 replication. The T CD4 $4^{+}$lymphocytes in a gastrointestinal mucosal express a greater percentage of CCR5 chemokine coreceptors than those in circulation with the same expression level of CXCR4 chemokine coreceptor. One study reported that both the $\mathrm{CD} 4{ }^{+} \mathrm{T}$-cell percentage and $\mathrm{CD} 4: \mathrm{CD} 8$ ratio in the mucosa of subjects with primary HIV infection was significantly lower compared to those in peripheral blood. ${ }^{38}$
Activation of T-cells and HIV replication in the anal and rectal mucosa due to the loss of specific $\mathrm{TCD}^{+}$ lymphocytes clones in the gastrointestinal tract accelerates the immunosenescent process. The anorectal epithelium shows the highest probability of HIV-transmission than oral and genital. The gastrointestinal tract is the main source of lymphocytes in the body with a predominance of $\mathrm{CD} 4^{+}$ T-cells that express CCR5. The anal mucosal epithelium is susceptible to damage during anal intercourse resulting in increased transmission and HIV infection of CD4 in lamina propria. Cervico-vaginal fluids contain vaginal transudate, mucus, antimicrobial factors, chemokines, and cytokines (defensins, SLPI, Elafin, RANTES, and CCL2) that have been associated with protection against HIV infection. Ectocervical and vaginal mucosae also consist of the multi-stratified epithelium with tight junctions in the deepest monolayers of cells. The inner foreskin has a higher frequency of HIV target cells such as $\mathrm{T} \mathrm{CD4}^{+}$ lymphocytes, Langerhans, macrophages, and DCs.

Mucosal foreskin epithelium in circumcised male is removed, thus leaving a dry keratinized epithelial surface which is more resistant to HIV infection as demonstrated in-vitro and in-vivo. ${ }^{9,38,39}$

The prevalence of $C D 4: C D 8$ ratio $<0.3$ in patients with a length of HIV infection $>5$ years $(1 / 5)$ times was significantly lower than that of $0-5$ years. The $\mathrm{CD}^{+} \mathrm{T}$-cells percentage continued to decline in chronic HIV-infected subjects without ARV. Normalization of CD4:CD8 ratio to 2.9 occurred after complete ARV for two years. Patients on immediate and complete ARV therapy reducing the interval between the diagnosis and the initiation of $A R V$ and increasing the possibility of normalization of CD4:CD8 ratio. ${ }^{38}$

The prevalence of $C D 4: C D 8$ ratio $<0.3$ in subjects with ARV for $0-5$ years was 4.628 times significantly higher than that of $>5$ years. The probability of normalization ratio after 5 years of ARV occurred in $6.1 \% ; 21 \% ; 16 \%$ and $4.5 \%$ subjects with baseline $\mathrm{CD}^{+} \mathrm{T}$-cells $<200$, baseline CD4 ${ }^{+} \mathrm{T}_{\text {-cells }}>350$, baseline $\mathrm{CD} 8^{+} \mathrm{T}$-cells $<500$ and baseline $\mathrm{CD} 8^{+} \mathrm{T}$-cells $>1150$ cells $/ \mu \mathrm{L}$. The baseline $\mathrm{CD}^{+}{ }^{+} \mathrm{T}$-cells, time-updated HIV RNA suppression, and sexual relations other than partners were thought to have contributed to its normalization. ${ }^{21}$ Saracino et al. proved that $37 \%$ of the subjects achieved normal CD4:CD8 ratio $\geq 0.9$ (median 0.42 ; baseline 0.16 ) with median 16 years of ARV treatment and the progression of $C D 4: C D 8$ ratio without plateau phase with significant differences at baseline CD4:CD8, 
baseline \% CD4 ${ }^{+}$T-cells, CD4 ${ }^{+}$T-cells, $\%$ CD4 ${ }^{+}$T-cells, $\mathrm{CD}^{+}{ }^{+}$T-cells and \% CD8 ${ }^{+}$T-cells. $^{40}$ Mussini et al. suggested that $12 \%$ of subjects achieved normal ratio within two years. ${ }^{23}$ Thornhill et al. reported that the subjects with a wider interval between seroconversion and the initiation of ARV had less probability to achieve ratio normalization. ${ }^{41}$ The $\mathrm{CD} 4^{+}$ T-cells count and baseline $\mathrm{CD}^{+}{ }^{+} \mathrm{T}$-cells were significantly lower in the CD4:CD8 $<0.3$ group. The prevalence of $C D 4^{+} \mathrm{T}$-cells $\leq 500$ cells $/ \mu \mathrm{L}$ in subjects with an ARV duration of $0-5$ years in this study proved to be significantly 3.72 times higher than that of $>5$ years.

Multivariate analysis showed that age, gender, and the length of HIV infection were significantly associated with $\mathrm{CD} 4^{+} T$-cells, whereas the duration of HIV and sexual behavior were significantly associated with CD4:CD8 ratio. Some literatures suggested that probability can be calculated using equation of $p=1 /[1+\exp (-y)], \quad p=p r o b a b i l i t y$, $y=$ constanta $+B 1(x 1)+B 2(x 2)+$ etc. The values of constanta, B1, B2 from B column of SPSS 21, table were input as variables in the equation table. Value $x 1, x 2$, etc. should be filled by one or zero. ${ }^{42,43}$ The probability of $C D 4^{+} T$-cells $\leq 500$ cells $/ \mu \mathrm{L} \quad$ can be calculated with the formula $y=0.185+1.181$ (gender) +1.239 (age)-1.304 (duration of HIV). The probability of $\mathrm{CD}^{+} \mathrm{T}$-cells $\leq 500$ cells $/ \mu \mathrm{L}$ in subjects aged $>42$ y.o. on ARV was $80.60 \%$. The probability of $\mathrm{CD}^{+}{ }^{+}$T-cells $\leq 500$ cells $/ \mu \mathrm{L}$ in male subjects was $79.67 \%$. The probability of $C D 4^{+} \mathrm{T}$-cells $\leq 500$ cells $/ \mu \mathrm{L}$ in male subjects aged $>42$ y.o. was $93.12 \%$. The probability of $\mathrm{CD} 4^{+} \mathrm{T}$-cells $\leq 500$ cells $/ \mu \mathrm{L}$ in male subjects aged $>42 \mathrm{y}$.o. with the duration of HIV $>5$ years was $78.60 \%$. The probability of CD4:CD8 $<0.3$ can be calculated with formula $p=1 /[1+\exp (-y)]$, $p=$ probability, $y=$ konstanta $+1,274$ (sexual behavior)2,083 (duration of HIV). The probability of CD4:CD8 < 0.3 in subjects with anal sexual behavior was $75.93 \%$, whereas the probability of CD4:CD $<0.3$ in subjects

Table 4. Logistic regression analysis of variables with $\mathrm{TCD}^{+}$

\begin{tabular}{lclc}
\hline Variable & PR & 95\% CI & P \\
\hline Model 1 & & & \\
Gender & 3.256 & $1.07-9.91$ & $0.038^{\star}$ \\
Age & 3.451 & $1.01-11.74$ & $0.047^{*}$ \\
Length of HIV & 0.271 & $0.09-0.82$ & $0.020^{\star}$ \\
\hline
\end{tabular}

${ }^{*} \mathrm{p}<0.05$ : significant, PR: Prevalence Ratio, HIV: Human Immunodeficiency Virus; CI: Confidence Interval; CD: Cluster of Differentiation
Table 5. Logistic regression analysis of variables with CD4:CD8 ratio

\begin{tabular}{|c|c|c|c|}
\hline Variable & PR & CI 95\% & $\mathbf{P}$ \\
\hline \multicolumn{4}{|l|}{$1^{\text {st }}$ model } \\
\hline Sexual behavior & 3.575 & $1.006-12.705$ & $0.049 *$ \\
\hline $\begin{array}{l}\text { length of HIV } \\
\mathbf{2}^{\text {nd }} \text { model }\end{array}$ & 0.125 & $0.036-0.431$ & $0.001^{*}$ \\
\hline & 0.698 & $0.184-2.655$ & 0.598 \\
\hline & 4.437 & $0.977-20.150$ & 0.054 \\
\hline $\begin{array}{l}\text { length of HIV } \\
\mathbf{3}^{\text {rd }} \text { model }\end{array}$ & 0.116 & $0.033-0.415$ & $0.001^{*}$ \\
\hline Gender & 0.686 & $0.178-2.644$ & 0.584 \\
\hline Sexual behavior & 4.193 & $0.824-21.342$ & 0.084 \\
\hline Syphilis infection & 1.177 & $0.201-6.895$ & 0.857 \\
\hline length of HIV & 0.115 & $0.032-0.414$ & $0.001^{*}$ \\
\hline
\end{tabular}

${ }^{*} \mathrm{p}<0.05$ : significant, CI: Confidence Interval, CD: Cluster of Differentiation, PR: Prevalence Ratio, HIV: Human Immunodeficiency Virus

with anal sexual behavior and duration of HIV $>5$ years was $28.21 \%$.

Cross-sectional design in this study may yield relationship among variables remained unclear. Better and clear relationship in next research will be achieved by adding adherence, hormonal effects, type and duration of antibiotic usage, frequency of changes in ARV regiment, differences in HIV-ARV duration and delta $C D 4^{+} \mathrm{T}$-cells in analysis and using case control or cohort design.

\section{CONCLUSION AND SUGGESTION}

There was no significant association between syphilis infection and the immunity of HIV patients on ARV based on T CD4 ${ }^{+}$count and CD4:CD8 ratio. The length of HIV, gender, and age was significantly associated with $\mathrm{TCD}^{+}{ }^{+}$count, while the length of HIV and sexual behavior were significantly associated with CD4:CD8 ratio. Age, gender, and length of HIV potentially affected the probability of $\mathrm{TCD}^{+} \leq 500$. Sexual behavior and duration of HIV potentially affected the probability of $C D 4: C D 8<0.3$. It was recommended to measure $\mathrm{CD} 4^{+} \mathrm{T}$-cells count and CD4:CD8 ratio at baseline and follow-up.

\section{REFERENCES}

1. Mahon CR, Donald CL, George M. Textbook of diagnostic microbiology. $4^{\text {th }}$, Missouri, WB Saunders Company, 2011; 539-47.

2. Male $D$, Jonathan $B$, David $B R$, Ivan MR. Immunology. $8^{\text {th }}$. China, Elsevier, 2013; 277-88. 
3. Prabowo Y. Profil kesehatan Provinsi Jawa Tengah tahun 2017 [Internet]. Dinas Kesehatan Provinsi Jawa Tengah. 2018 [accessed 4 September 2018]. Available from: https://www.kemkes.go.id/resources/ download/profil/PROFIL_KES_PROVINSI_2017/ 13_Jateng_2017.pdf.

4. Wahyuningsih S. Profil kesehatan Kota Surakarta tahun 2017 [Internet]. Dinas Kesehatan Kota Surakarta. 2018 [accessed 5 September 2018]. Available from: https://www.kemkes.go.id/ resources/download/profil/PROFIL_KAB_KOTA_2017 /3372_Jateng_Kota_Surakarta_2017.pdf.

5. Hastuti R. Peran faktor risiko terhadap prevalensi infeksi menular seksual dan infeksi HIV pada wanita pekerja seks di Surakarta [Thesis]. Surakarta, Fakultas Kedokteran Universitas Sebelas Maret, 2018. Available from https://eprints.uns.ac.id/40966/ (accessed 4 September 2018).

6. Chandrasekar PH. Syphilis. Editor: Michael SB. [Internet]. Medscape. 2017 [cited 5 September 2018]. Available from: https://emedicine.medscape. com/article/229461-overview\#showall.

7. Torok E, Ed M, Fiona C. Oxford handbook of infectious diseases and microbiology. $2^{\text {nd }}$., United Kingdom, Oxford University Press, 2017; 333-37,714-16, 819-42.

8. Li Z, Lu X, Hu Z, Luo Z, Jiang W, et al. Syphilis infection differentially regulates the phenotype and function of yठ T-cells in HIV-1-infected patients depends on the HIV-1 disease stage. Front Immunol, 2017; 8: 991.

9. Klatt EC. Pathology of HIV/AIDS. $30^{\text {th }}$., Savannah, Mercer University School of Medicine, 2019; 35-100.

10. Tsai HC, Ye SY, Lee SS, Wann SR, Chen YS. Expression of CXCL2 in the serum and cerebrospinal fluid of patients with HIV and syphilis or neurosyphilis. Inflammation, 2014; 37(3): 950-5.

11. Shilaih M, Marzel A, Braun DL, Scherrer AU, Kovari H, et al. Factors associated with syphilis incidence in the HIV-infected in the era of highly active anti-retrovirals Medicine (Baltimore). 2017; 96(2): e5849.

12. Casotti JA, Passos LN, Oliveira FJ, Cerutti C Jr. Factors associated with paradoxical immune response to anti-retroviral therapy in HIV infected patients: A case control study. BMC Infect Dis, 2011; 11: 306.

13. Annison L, Dompreh A, Adu-Sarkodie Y. The immunological response of HIV-positive patients initiating HAART at the Komfo Anokye Teaching Hospital, Kumasi, Ghana. Ghana Med J, 2013; 47(4): 164-70.

14. Teshome, W, Assefa A. Predictors of immunological failure of anti-retroviral therapy among HIV infected patients in Ethiopia: A matched case-control study. PLos One, 2014; 9(12): e115125.

15. Uppal SS, Verma S, Dhot PS. Normal values of CD4 and CD8 lymphocyte subsets in healthy Indian adults and the effects of sex, age, ethnicity, and smoking. Cytometry B Clin Cytom, 2003; 52(1): 32-36.

16. Prasetyo AA, Zaini KU. Establishing mean CD4+ T-cell values among healthy Javanese adults in Indonesia. South East Asian J Trop Med Public Health, 2015; 46(4): 662-8.
17. Yusra E, Efrida E, Elmatris SY. Hubungan karakteristik klinis dengan pemulihan respons imun penderita HIV-1 yang mendapat terapi anti-retroviral di RSUP Dr. M. Djamil Padang. Jurnal Kesehatan Andalas, 2018; 7(3): 436-442.

18. World Health Organization. Interim WHO clinical staging of HIV/AIDS and HIV/AIDS case definitions for surveillance. Afrika, WHO, 2005; 1-15.

19. Pedoman Nasional Pelayanan Kedokteran Tata Laksana HIV (PNPK-HIV 2019). Keputusan Menteri Kesehatan Republik Indonesia Nomor HK.01.07/MALEKES/90/2019. 2019; 1-100.

20. Susilowati T. Faktor -faktor risiko yang berpengaruh terhadap kejadian HIV dan AIDS di Semarang dan sekitarnya. Komunikasi Kesehatan,Ed 2., P3M AKBID Purworejo, 2011; 2(01): 1-16.

21. Leung V, Gillis J, Raboud J, Cooper C, Hogg RS, et al. Predictors of CD4:CD8 ratio normalization and its effect on health outcomes in the era of combination anti-retroviral therapy. PLoS One, 2013; 8(10): e77665.

22. Bellissimo F, Pinzone MR, Celesia BM, Cacopardo B, Nunnari G. Baseline CD4/CD8 T-cell ratio predicts prompt immune restoration upon cART Initiation. Curr HIV Res, 2016; 14(6): 491-496.

23. Mussini C, Lorenzini P, Cozzi-Lepri A, Lapadula G, Giulia $M$, et al. CD4/CD8 ratio normalisation and non-AIDS-related events in individuals with HIV who achieve viral load suppression with anti-retroviral therapy: An observational cohort study. Lancet HIV, 2015; 2(3): e98-e106.

24. Venter WDF, Matthew FC, Mohammed M, Godspower A, Natasha A, et al. CD4 cell count variability with repeat testing in South Africa: Should reporting include both absolute counts and ranges of plausible values?. International Journal of STD \& AIDS, 2018; 29(11): 095646241877176.

25. Wade D, Daneau G, Aboud S, Vercauteren GH, Urassa WS, Kestens L. WHO multicenter evaluation of FACSCount CD4 and Pima CD4 T-cell count systems: Instrument performance and misclassification of HIV-infected patients. J Acquir Immune Defic Syndr, 2014; 66(5): e98-e107.

26. Prana Iswara Ni Putu Ayu Astri, Sutarsa I Nyoman, Sawitri Anak Agung Sagung. Prediktor immunological failure pada pasien HIV/AIDS di Yayasan Kerti Praja, Bali: Studi kohort retrospektif. E-Jurnal Medika Udayana, 2018; 7(3): 133-139.

27. Adiningsih S, Mirna W, Evi IN, Tri W. CD4+ dan faktor yang mempengaruhi kepatuhan terapi anti-retroviral pada orang dengan HIV/AIDS di Jayapura. Buletin Penelitian Kesehatan, 2018; 46(2): 87-96.

28. Saktina PU, Bagus KS. Karakteristik penderita AIDS dan infeksi oportunistik di Rumah Sakit Umum Pusat Sanglah Denpasar periode Juli 2013 sampai Juni 2014. E-Jurnal Medika Udayana, 2017; 6(3): 1-6.

29. Rueda S, Raboud J, Rourke SB, Bekele T. Influence of employment and job security on physical and mental health in adults living with HIV: Cross-sectional analysis. Open Med. 2012; 6(4): e118-e126.

30. Kambu Y. Analisis faktor-faktor yang mempengaruhi 
tindakan pencegahan penularan HIV oleh ODHA di Sorong [Thesis]. Jakarta, Fakultas Ilmu Keperawatan Universitas Indonesia. 2012. Available from http://lib.ui.ac.id/file?file= digital/20298197-T30126Analisis\%20faktor-faktor.pdf (accessed 30 April 2019).

31. Shisana O, Risher K, Celentano DD, Zungu N, Rehle T, et al. Does marital status matter in an HIV hyperendemic country?. Findings from the 2012 South African National HIV prevalence, incidence and behaviour survey. AIDS Care, 2016; 28(2): 234-241.

32. Olsen NJ, Kovacs WJ. Evidence that androgens modulate human thymic T-cell output. J Investig Med, 2011; 59(1): 32-35.

33. Meditz AL, Folkvord JM, Lyle NH, Searls K, Lie YS, et al. CCR5 expression is reduced in lymph nodes of HIV type 1-infected women, compared with men, but does not mediate sex-based differences in viral loads. J Infect Dis, 2014; 209(6): 922-930.

34. Su S, Li S, Li S, Gao L, Cai Y, et al. Gaps in the continuum of HIV Care: Long pretreatment waiting time between HIV diagnosis and anti-retroviral therapy initiation leads to poor treatment adherence and outcomes. Biomed Res Int. 2016; 2016: 2648923.

35. Nakanjako D, Ssewanyana I, Mayanja-Kizza H, Kiragga A, Colebunders R, et al. High T-cell immune activation and immune exhaustion among individuals with suboptimal CD4 recovery after 4 years of anti-retroviral therapy in an African cohort. BMC Infect Dis, 2011; 11: 43.

36. Gras L, Kesselring AM, Griffin JT, van Sighem AI, Fraser C, et al. CD4 cell counts of 800 cells/mm3 or greater after 7 years of highly active anti-retroviral therapy are feasible in most patients starting with 350 cells $/ \mathrm{mm} 3$ or greater. J Acquir Immune Defic Syndr, 2007; 45(2): 183-192.

37. Xiao J, Xu L, Gao G, Wu L, Wang F, Yang D, Zhao H. Syphilis influences the CD4/CD8 ratio and a scoring model predicts normalization of CD4/CD8 ratio in HIV-infected patients. In: $3^{\text {rd }}$ Asia Pacific AIDS \& co-infections conference. Reviews in Antiviral Therapy \& Infectious Diseases, 2018; 7: 76.

38. Mehandru S, Poles MA, Tenner-Racz K, Horowitz A, Hurley $A$, et al. Primary HIV-1 infection is associated with preferential depletion of CD4+ T lymphocytes from effector sites in the gastrointestinal tract. J Exp Med, 2004; 200(6): 761-70.

39. Gonzalez SM, Aguilar-Jimenez W, Su RC, Rugeles MT. Mucosa: Key interactions determining sexual transmission of the HIV infection. Front Immunol, 2019; 10: 144.

40. Saracino A, Giuseppe B, Luigia S, Anna V, Pierluigi C, et al. Chronic inflammation in a long-term cohort of HIV-infected patients according to the normalization of the CD4:CD8 ratio. AIDS Research and Human Retroviruses, 2014; 30(12): 1178-84.

41. Thornhill J, Inshaw J, Kaleebu P, Cooper D, Ramjee G, et al. Brief report: Enhanced normalization of CD4/CD8 ratio with earlier anti-retroviral therapy at primary HIV infection. J Acquir Immune Defic Syndr, 2016; 73(1): 69-73.

42. Dahlan MS. Statistik untuk kedokteran dan kesehatan. 6th., Jakarta, Epidemiologi Indonesia, 2015; 92-105.

43. Prihanti GS. Pengantar biostatistik. 1 $1^{\text {st. }}$, Malang, Universitas Muhammadiyah Malang, 2016; 302-18. 